\title{
Designing Online Collaborative Location-Aware Platform for History Learning
}

\author{
Xiaojun Chen \\ Jea H. Choi \\ Purdue University
}

\begin{abstract}
The emergence of geographic visualization and location aware technologies provides educators and teachers with an opportunity to design more effective instructional materials. Visible Past is an innovative learning and discovery project that integrates mapping services with a content management system and $3 D$ virtual reality capabilities. In addition, the system allows for the connection of physical locations or objects such as books and digital artifacts and documents through 2D codes. Similar to barcodes, they can be read by any camera enabled cell phone triggering information retrieval from the web. This adds an element of portability and of meshing up print based media with digital information to the educational process. This paper describes a recent attempt to integrate a location-aware platform into the high school history curriculum. Authors have reviewed the literature related to online history inquiry activity (i.e. collaborative and reflective learning in history), as well as to newly innovative context-aware learning theory. The process of the module design is described and grounded in the literature. Learning effects and future development paths of proposed technology are discussed.
\end{abstract}

Keywords: instructional design, online inquiry, location awareness, history education

\section{Introduction}

The emergence of geographic visualization and location aware technologies provides educators and teachers with an opportunity to design more effective instructional materials. A new generation of online tools, such as social networking, annotating and sharing, as illustrated by Facebook, Evernote, Qik, Mandeley, or Diigo, has transformed the unilateral relationship between users and content (O'Reilly, 2005) to a multilevel, many-to-many network of ties between individuals, content, locations or other individuals (LearnNC, 2009).
In recent years, e-learning researchers have noticed that the progress of ubiquitous access technologies, such as "smart" cell phones, could be extended to learning and discovery as well. However, the current state of employing digital humanities in teaching is several steps behind the most innovative developments that have taken the Internet from passive desktop publishing to 'social media' or from text to 3D immersive virtual realities (Matei, 2009). In order to assist teachers and instructional designers in the implementation of "social media" into teaching, researchers of this paper first reviewed the literature that underlies the 
important theories, which are effective for learning history in online environment. Two major aspects of theories are identified. First, the provision of providing an online activity for students to make historical inquiry ( $\mathrm{Li} \& \mathrm{Lim}$, 2008), applying question prompts and peer interaction as scaffolding strategies is needed. Secondly, it is important to provide students with a context rich environment (Patten, Sanchez, \& Tangney, 2006).

\subsection{Online Inquiry Activity}

Students are expected to think like historians (Li \& Lim, 2008; Smith, 1996). The National Council for the Social Studies claimed that students are expected to "systematically employ processes of critical historical inquiry to reconstruct and reinterpret the past, such as using a variety of sources and checking their credibility, validating and weighing evidence for claims, and searching for causality" (National Council for the Social Studies, 1994, p. 40). The Internet and its applications have broadened the horizon for history teachers to design such inquiry learning activities (Rogers $\&$ Swan, 2004). Online activity in the history class offers great opportunity for learning. Online inquiry activity provides students a more engaging environment (Cantu \& Warren, 2003; Doppen, 2004; Sunal \& Sunal, 2003). It motivates students to focus to investigate more deeply into the content knowledge (Edelson, Gordin, \& Pea, 1999). It helps cultivating students' self-directed learning (Lim, 2004). However, one important aspect to assure inquiry activity promotes meaningful learning is to provide appropriate guidance or scaffolding in the online environment ( $\mathrm{Li} \&$ Lim, 2008; Molebash, 2004). Prior studies have been conducted and revealed several problems for students who participated in online activities. Li and Lim (2008) reviewed studies in this area and summarized two main problems that students might encounter in online inquiry activities. Students might lack the needed information literacy to be able to utilize the information they found on the Web (Wallace, Kupperman, Krajcik, \& Soloway, 2000). Furthermore, the process of inquiry in online environment requires high cognitive skills (Wegner, Holloway, \& Garton, 1999). Thus, Li and Lim (2008) suggested employing appropriate scaffolding strategies to facilitate students' learning in online history inquiry activities. Question prompts and peer interaction have been reviewed as effective scaffolding strategies in an online learning environment (Ge \& Land, 2003). Collaboration and feedback can be gained through peer interaction, and the question prompts guide students' inquiry process as well as their reflective thinking process.

\subsection{Context-aware / Location-aware}

A context-aware ubilearning is an effective learning model which enables one to sense the personal and environmental contexts to provide adaptive supports to the learners (Hwang, Yang, Tsai, \& Yang, 2009). According the Hwang, Tsai, \& Yang, (2008) the criteria of a context-aware ubilearning environment are: (a) the context-aware ubilearning environment senses the real-world environment in which the learner is located; (b) a context-aware ubilearning environment is able to offer more adaptive supports to the learners by taking into account their learning behaviors and contexts in both cyber and real space; (c) a context-aware ubilearning environment can actively provide personalized learning support in the right way, at the right place, and right time, based on the personal and environmental contexts derived from real world activities, as well as from the online profile and learning portfolio of the learner; (d) a context-aware ubilearning environment enables seamless learning from place to place within the predefined area; and 
(e) a context-aware ubilearning environment is able to adapt the subject content to meet the functions of various mobile devices.

Location awareness falls into the context-awareness category which aims to contextualize learning activities by enabling the learners to interact appropriately with their environment (Patten, Sanchez, \& Tangney, 2006). Achieving location information or being in the actual place helps students to learn and memorize about the learning context. Application of location awareness could be used in various learning environments such as on the field trip, with the use of maps, or even in virtual reality (Forsyth, 1986; Hwang, et al., 2009; Michie, 1998; Patten, et al., 2006). The study of Forsyth (1986) has shown that those students who used maps during the adventure game memorized significantly more information than those who did not use any map. Michie (1998) insisted that field trips were valuable for students' cognitive and affective development. In addition, Michie mentioned that due to both school administration policies and other budgetary problems, field trips were usually discouraged. However, with technological development and wireless communication provided, the chance of applying location awareness has been increased without going to the actual site. A simple example of using location awareness in modern technology would be a museum tour. This type of application is representative of delivering content appropriate to the learner's position (Pattern, et al., 2006). Similar to this approach, a teaching scenario of using Website information with Internet mapping service such as Google map has been introduced (Matei, et al., 2007). Matei (in press) mentioned that online platforms with mapping tools better retain each student's attention and help to engage collaborative learning as well.

\section{Visible Past Platform and Learning Technologies}

With the guidance of the four major theories, the authors of this paper are designing a collaborative mapping and knowledge management platform named Visible Past (http://tinyurl.com/visiblepastdday), where the goal is to create educational and discovery environments for researchers and students alike. One of its main characteristics is that it is location-aware. If the user's location is provided through a GPS, mobile or mapping/ 2D code interface, the platform will deliver the user information that is relevant for that location. The ultimate goal of the system is to un-tether humanities education from physical confines and to promote the pervasive sharing of tools or knowledge across virtual and real space. In addition to the usual hyperlinking records of events, research narratives and artifact metadata are accessible by geographic and temporal coordinates (Matei, Wernert, $\&$ Faas, 2009). The present paper discusses a possible use scenario for the Visible Past, namely to integrate it into the classroom setting via $2 \mathrm{D}$ codes attached to textbooks and learning materials. The $2 \mathrm{D}$ code is a kind of two dimensional code developed in the Japanese automotive manufacturing industry (Denso Wave Inc., 2003). It was recently being implemented by educational pioneer researchers in Japan (Chaisatien \& Akahori, 2007), Taiwan (Chu \& Liu, 2007), and US (Matei, in press).

A development team of Visible Past aims to integrate innovation and to develop practical uses for ubiquitous technologies in education, learning, and training as suggested by Hwang and others (2008). Visible Past utilizes as a learning showcase a model of Omaha Beach fortifications at the time of the Allies' landing on the morning of June 6, 1944 (D-Day). The model includes the full set of two dozen German 
fortifications (Wiederstandnest or, in German military parlance, $\mathrm{WN}$ ) that the American 1st and 29th divisions encountered on the morning of June 6, 1944. Each WN includes a barbed wire enclosure and one or more points of fire: pillboxes, bunkers, mortar pits or field gun encasements. Many of the artifacts were provided by 3D weapons collections found at the Google Earth 3D Warehouse repository; some of them were reconstructions produced by the Visible Past team members. The 3D artifacts were selected and evaluated according to the historical literature dedicated to Omaha beach (Virtual Omaha Beach Showcase, 2010).

Visible Past is not just a simple visualization tool, but a one of a kind historical information repository. All 3D locations of German fortification are supplemented with historical information about the German or American military units and of the events of that momentous day. Information includes names of specific individuals, historical and present day pictures of the buildings and weapons found at each location, and historical or fiction movie clips referring to Omaha Beach. Information points are displayed as map markers. Upon activation through mouse clicks, the markers call up a variety of resources including text, audio or YouTube clips from Saving Private Ryan, The Longest Day, and from contemporary German and
Allied newsreels. Pages attached to the model also contain user contributed photographs distributed through Picasaweb or Flickr. They depict past or present images of specific pillboxes, events, or personalities involved in D-Day operations at Omaha Beach (Matei, in press). In this paper, we focus on the use of this model in a typical high school history class which deals specifically with World War II.

The present activity revolves around the idea of creating hyperlinks to digital information (text, audio, and video) through 2D codes which are attached to printed materials, primarily in textbooks. The scenarios proposed here promote a vision of ubiquitous and context aware learning (ubilearning). Visible Past includes a utility that generates a 2D code for each webpage. The code can be printed out and attached to any object. Figure 1 shows the textbook page inserted with 2D code. When scanned with an iPhone or other type of camera ready smartphone (or even a webcam), the digital device will trigger the downloading of the resource whose URL is encrypted in the 2D code. Figure 2 shows the procedure of the iPhone application. Activities can take place anywhere as long as iPhones are available. In absence of iPhones, regular computers can be used, with or without a camera.

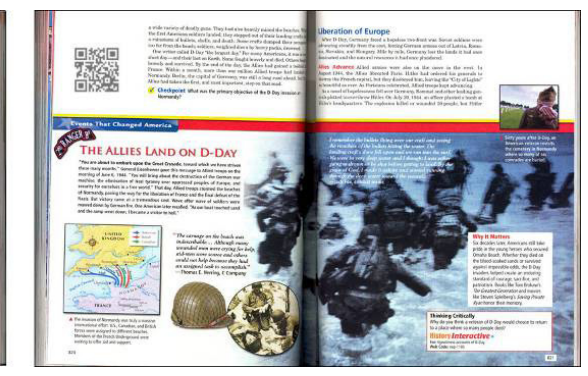

Figure 1. High school American history textbook with 2D code inserted 


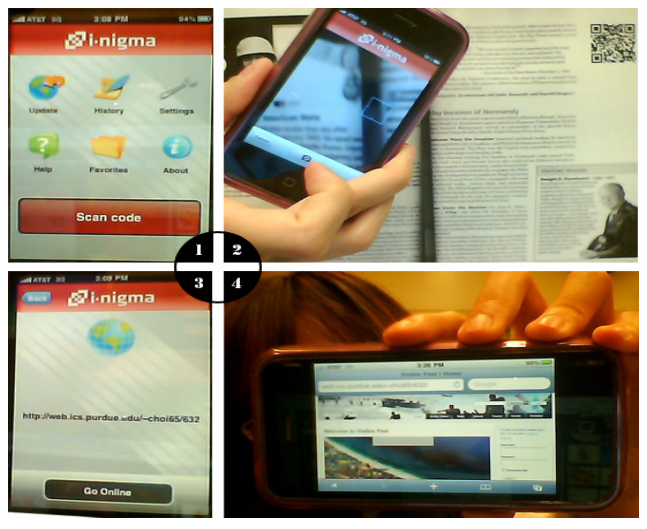

Figure 2. Procedures of iPhone application of 2D code and the website

\section{Design of the Learning Module}

The systematic design approach (Smith \& Ragan, 2004) was utilized to develop the Omaha Beach module. Figure 3 outlines the four steps of the design and development process: conduct learner, content and task analysis; design the platform according to literature and analysis; develop and modify the prototype; and planned future user evaluation.
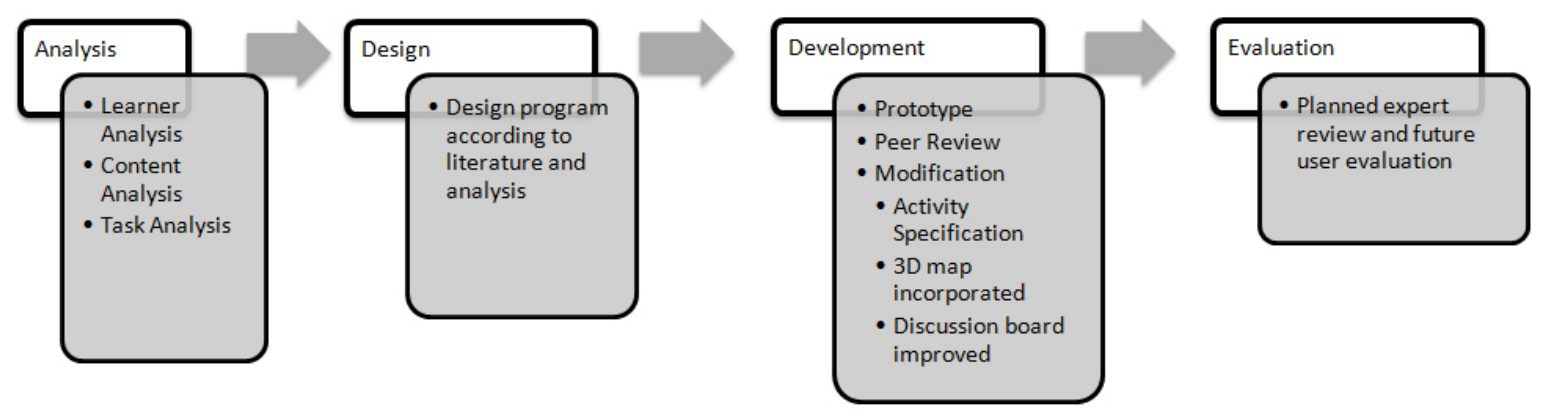

Figure 3. Design process of Visible Past

Designers conducted learner analysis, task analysis, and content analysis for this module. A learner analysis was conducted from four major aspects: students' cognitive characteristics, psychological characteristics, affective characteristics, and social characteristics. For general learners at Grade 9 or 10, students have intermediate reading level, and they have basic information literacy. Students are able to conduct critical thinking and highorder thinking. Students are comfortable with technology and socially active with peer students by using social media technology (Rulsinelli \& Roubie, 2001) such as Facebook and twitter. The design implication from the learner analysis is to incorporate social interactive elements into the module activity, and to build social components into the course platform such as activity update and group workspace.

Designers used a United States History text book for content analysis (Lapsansky-Werner, Levy, Roberts, \& Taylor, 2007). Designers 
linked the information with specific pages in high school American history textbook. Contents were uploaded to the framework according to the area whether the event took place. The design consideration from the content analysis is to give a geographical sense linked to the historical event.

Three major steps were conducted in task analysis: determining the goal for the program, listing expected outcome, and identifying steps and tasks for the goal. Ultimate goal for the program was to enhance the understanding of American History. Expected outcome is that students will be able to recall the historical events with geographical information. In order to achieve the goal, several tasks are proposed: using collaborative activities such as group discussion to share students' thoughts, provide maps with marked events, and provide guided questions.

After the analysis and literature review, designers developed a prototype for the program. After the prototype was developed, designers created a user scenario and conducted an alpha testing. This prototype was peer reviewed by a panel with seven graduate students and one professor in digital media and communication. Feedback was given in an open forum format. The program was modified by adding more specific activities, incorporating 3D map features, and improving discussion board. Expert review and user evaluation is planned for the future development.

There are many design challenges that designers of Visible Past have faced. After conducting the analysis, the designers realized that it is difficult to find a pre-packaged courseware for this module. The designers produced a prototype using the Wordpress platform. Once the selection of Wordpress as a basic platform was done, the designers had to collaborate various add-ons to develop the desired program. Because it had to use three or four different functions from different vendors, designers had to test the applications. Moreover, website design seemed to appear different for each web browsers (Safari, Opera, Internet Explorer, Google Chrome, and Firefox). According to browser statistics from W3School (2010), Firefox is the most popular browser, thus the designers decided to build the program referring to Firefox appearance.

The learning activity design was guided by collaborative learning theory (Brandon \& Hollingshead, 1999; Gokhale, 1995), as well as by prior research in designing online environments for history and social disciplines (Saye \& Brush, 2002). A lesson plan was also created to align the standards, teaching objectives and learning activities described in this online module (Appendix 1). When a student comes to the home page, he will find eight menu tabs on the right top of the page: Home, About, D-Day library, Maps, Groups, Forums, Activity, and Members. The content, relationships with one another, and their underlying learning theories of these menus are illustrated in Figure 4.

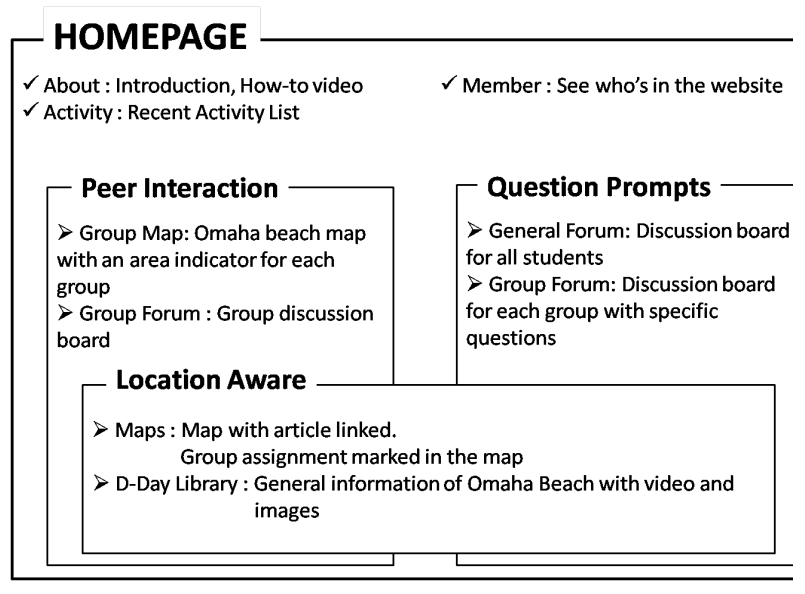

Figure 4. Sitemap of Visible Past 
Student learning was conceptualized into three phases. Phase 1 is designed to help students learn through guided questions about historical content (Ge \& Land, 2003). Phase 2 is designed to facilitate students' collaborative learning in small groups (Brandon \& Hollingshead, 1999). Phase 3 is designed to enhance students' reflective and critical thinking while studying historical topics (Saye \& Brush, 2002). In the next three sections, we discuss the integration of the platform in a future scenario.

\subsection{Module Phase 1}

The class will be divided to three groups. IPhones, Droid, or any smart, camera enabled, Internet connected phone can be provided to each group; all devices should have a freely available 2D code scanning application installed (i-nigma is preferred). If phones are not available, activity could be sustained by using a computer lab and the Visible Past website directly. Each group will be assigned to read the textbook and to conduct supplementary research about a certain area of Omaha Beach. Students will research the events that happen in their assigned area.
Students can use their textbooks and the 2D codes they find in them to complete their assignments. Handouts will be given with specific questions to guide them toward that for which they should look. According to Saye and Brush (2002), using guided questions in an online learning environment enhances students' history discipline inquiry skill. The design of this phase also echoes the design guidelines proposed by Ge and Land (2004), which is to extend the means of scaffolding by designing and embedding question prompts in educational computer programs. Students can use $2 \mathrm{D}$ codes in the textbook to access directly the information found on Visible Past. The information is complementary and richer. It includes information about the battle and its setting in a way that the textbook cannot convey. The $2 \mathrm{D}$ codes provided in the textbook led students to a group assignment screen (shown in Figure 5) with expanded story and movie clips (shown in Figure 6). Students will then be asked to make inquires about the events which happened in Omaha Beach, the role of United States in those events, as well as the consequences of those events in World War II.

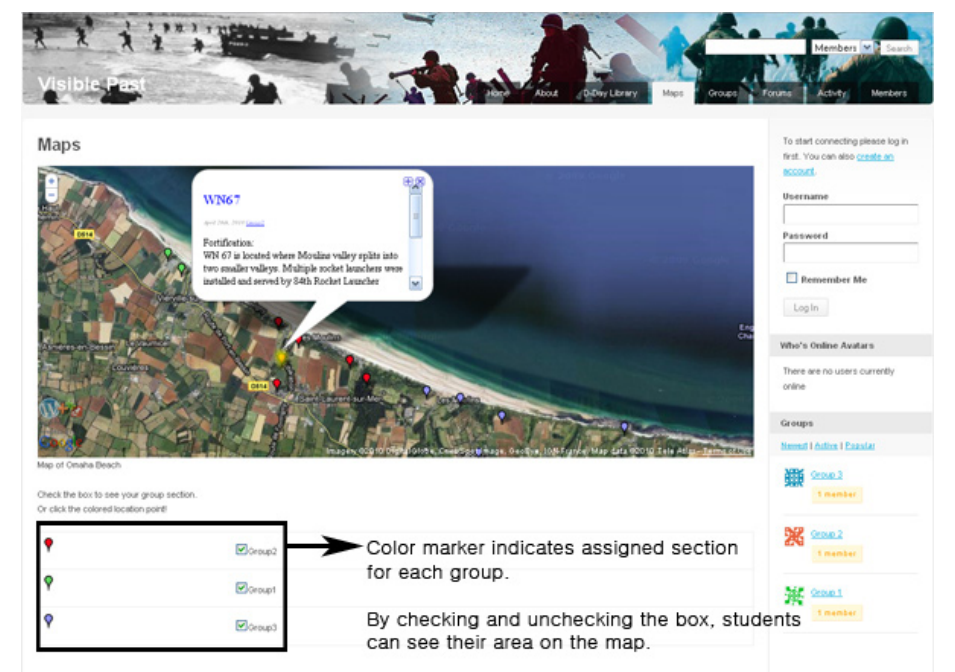

Figure 5. Screenshot of group assigned map 


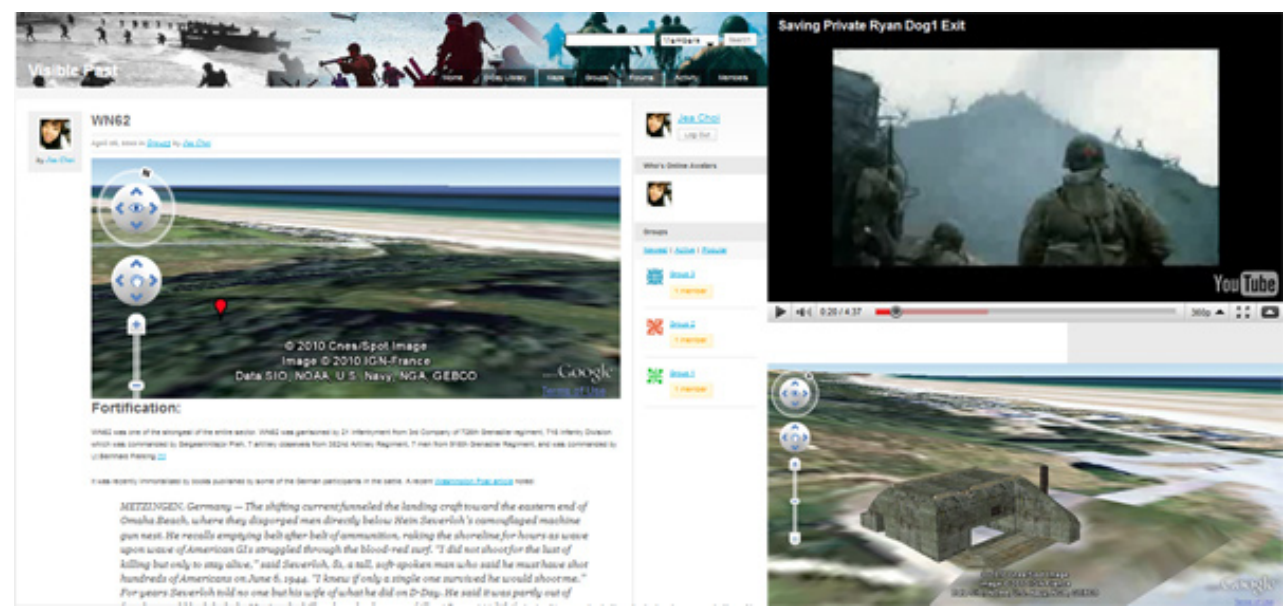

Figure 6. Screenshot of Visible Past website with videos and 3D map

\subsection{Module Phase 2}

Each group will present their findings to the whole class. All groups will collaborate on writing descriptions of the events and align these together by indicating the time when the events occurred and who has taken a part in them. Figure 7 provides students with (a) the 2D codes that linked with the website, and (b) the guiding questions to complete the assignment. The questions are divided into two parts. Students will be advised to record the events name and the date of the battle in the designated group area and to also answer the following four questions:
1. What happened in here?

2. Was the US involved in this event? If yes, what is the role of US?

3. List the leading person in this event.

4. What was the consequence of this event in WW II?

The second portion of the questions then asks the students to personally reflect on the event during their inquiry process, where they must answer: What strikes you most in this event? Please share an interesting story relates to D-day that you discovered in your research process.

\begin{tabular}{|c|c|c|c|c|c|c|c|}
\hline \multirow[t]{3}{*}{ Map Code } & \multicolumn{5}{|c|}{ Path of inquiry } & \multirow{2}{*}{\multicolumn{2}{|c|}{$\begin{array}{l}\text { Treasure of your contribution } \\
\text { Please work individually for these two parts. }\end{array}$}} \\
\hline & \multicolumn{5}{|c|}{ Please work in your team to fill in this part. } & & \\
\hline & $\begin{array}{l}\text { Event } \\
\text { name, } \\
\text { time } \\
\text { and } \\
\text { date }\end{array}$ & $\begin{array}{l}\text { What } \\
\text { happened } \\
\text { here? }\end{array}$ & \begin{tabular}{|l|} 
Did US \\
involve in \\
this event? If \\
yes, what is \\
the role of \\
US? \\
\end{tabular} & \begin{tabular}{|l|}
$\begin{array}{l}\text { list the } \\
\text { leading } \\
\text { person in } \\
\text { this } \\
\text { event. }\end{array}$ \\
\end{tabular} & \begin{tabular}{|l|} 
What was the \\
consequencee \\
of this event \\
in WW II?
\end{tabular} & $\begin{array}{l}\text { What strikes you } \\
\text { most in this } \\
\text { event? }\end{array}$ & \begin{tabular}{|l|} 
Please share an \\
interesting story relates \\
to D-day that you \\
discovered in your \\
research process.
\end{tabular} \\
\hline \multicolumn{8}{|l|}{ 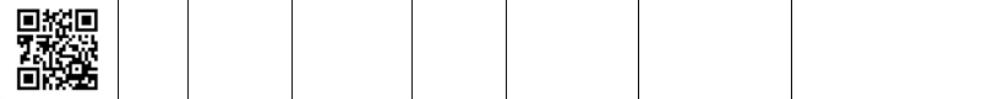 } \\
\hline \multicolumn{8}{|l|}{ 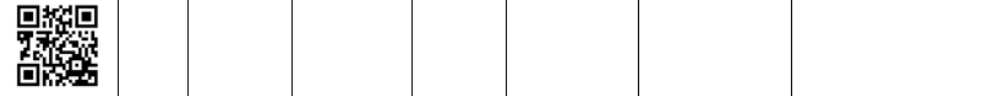 } \\
\hline 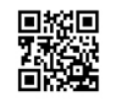 & & & & & & & \\
\hline & & & & & & & \\
\hline
\end{tabular}

Figure 7. Handout for group activity with question prompts 
This process engages students both in collaborative thinking and in working with their peers. Peer interaction and collaboration is advantageous for students in providing and receiving explanations, constructing ideas, resolving conflicts, and negotiating meaning (Ge \& Land, 2004). Collaboration and interaction with peer students will enable students to gain rich information and more detail about the context and the learning material. This will help students to participate in online discussion with peers in Phase 3.

\subsection{Module Phase 3}

Because Visible Past also includes social networking and social conversation spaces, students can participate in online discussions (Figure 8). They will be encouraged to answer the discussion questions specified below and to reflect on the activity. Students need to find an interesting story of D-day and to share it in the online discussion board as well. Discussion boards or forums are highly appropriate tools for promoting high-level educational discourses, which can also help students enhance their history content knowledge (Ge \& Land, 2004). Guiding questions are categorized into two sections: (1) path of inquiry, which guides students in acquiring content knowledge (Mayer, 2005); and (2) treasure of contribution, which facilitates students' critical reasoning and personal reflection upon their learning experiences (Gokhale, 1995). In addition, students can add more information to the Visible Past page if they find more resources. An evaluation could be completed through assessing students' responses to reflection and their participation in online activity.

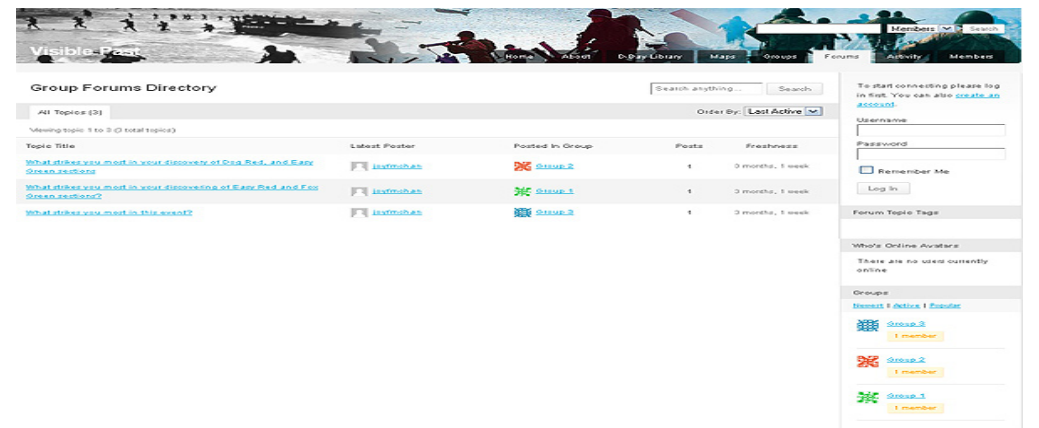

Figure 8. Group forum for student discussion

\section{Discussion}

Technology itself cannot make instruction effective nor make learning meaningful (Merrill, 2002; Wang \& Hannafin, 2005). Based on multimedia learning theory and reflective learning strategies, the lesson module presented in this paper was designed based on major learning theories and aims to provide a meaningful learning experience for students in their history class.
Researchers emphasize the interaction between the educational task and the nature or structure of the multimedia environment and this interaction is of primary importance in planning curriculum, designing multimedia technology, and researching the effectiveness of multimedia instruction (Wiley \& Ash, 2005). Using the combination of Visible Past and the textbook with embedded 2D codes for in-class presentations lends itself to an Interactive Lecture Demonstration activity, providing an ideal mechanism for creating an active 
classroom learning environment (Sokoloff \& Thornton, 1997).

Visible Past provides a dynamic environment to help students learning history content and practicing history inquiry skills. Visible Past brings opportunities for students in learning history in two major aspects. First, it is a multimedia platform with maps and videos, which provide students with richer information and deeper understanding of historical events (Mayer, 2005). The platform presented here integrates technology with classroom activities in a way that is convergent with those suggested by studies such as ACCESS (American Culture in Context: Enrichment for Secondary Schools) (Sopehr \& Sopehr, 1994). Research results from the ACCESS study showed that students participating in the hypermedia learning environment achieved higher scores on standard tests, created richer representations of historical topics, and wrote better essays than students in non-ACCESS classes. Similarly, Wiley and Ash (2005) found out that there were two major ingredients for designing effective history classes: a good grasp of the content matter and an adequate and student sensitive method for disseminating historical inquiry skills. The latter type of knowledge needs to be acquired through participation in highly structured, guided activities with a clear problem-solving or inquiry goal $\left(\mathrm{O}^{\prime}\right.$ Neill \& Sohbat, 2004). Visible Past strongly emphasizes this individual exploration and discovery of historical information. Students may benefit from this type of interactive, ubilearning instruction in that they are invited to participate in activities that are similar to those that historians use when judging and interpreting historical sources and evidence.

Visible Past also encourages students to participate in reflective learning (Light, Calkins, \& Cox, 2009) and collaborative learning. It provides technological creativity and small group learning in the history class. Smith (1996) reviewed reflective research in history and found that interactive strategies are very productive in engaging students in class activities and to practice their history inquiry skills. Students are invited to think as a historian as well as an independent researcher. The class is no longer a traditional lecture class, but a group-based learning community. Students can share their own discovery and that of the class both directly and through the online activity.

\section{Limitations}

The limitation of this study is that the designers focused on a single module. Users need to install Google add-on of the Google Earth in order to be presented by the 3D virtual environments. However, in the case of not being able to see the Google map 3D view, designers have provided users an alternative option to view the map in a hybrid mode. Although peer evaluation was taken in an open forum format, valuable advices and usability suggestions were taken into consideration in the development process. Due to the time constraints of the project development, the designers had limited resources and time to conduct evaluation on future users, either high school students or high school social studies teachers.

\section{Conclusion/Future Development}

Visible Past is an exemplary project to integrate the social networking platform into the history curriculum. The design process of this project sheds light on bridging the gaps between the theories of learning to actual teaching in classroom. The design process of Visible Past can help teachers or instructional designers to design specific modules for history teaching. In the future, the development team and researchers of the Visible Past would like 
to expand the scope of the learning modules in history. For example, more lesson plans can be created for other topics in American history other than World War II. Furthermore, field trip modules can be developed and expanded to other disciplines, too. For example, students can take mobile devices with 2D code recognition application to study geography, biology and sociology.

\section{Reference}

Balkoski, J. (2006). Omaha Beach: D-Day, June 6, 1944. Stackpole Books.

Bernage, G. (2002). Omaha Beach: 6/6/1944. Heimdal.

Brandon, D., \& Hollingshead, A. (1999). Collaborative learning and computersupported groups. Communication Education, 48(2), 109-126.

Cantu, D.A., \& Warren, W.J. (2003). Teaching history in the digital classroom. ME Sharpe: Armonk, New York.

Chaisatien, P., \& Akahori, K. (2007). A Pilot Study on $3 G$ Mobile Phone and Two Dimension Barcode in Classroom Communication and Support System. Paper presented at the International Conference on Advanced Learning Technologies, Niigata, Japan.

Chu, Y., \& Liu, T. (2007). Handheld Computer Supported Context-Aware Learning with $2 D$ Barcodes. Paper presented at the International Conference on Advanced Learning Technologies Niigata, Japan.

Denso Wave Inc. (2003). QR Code Features. Retrieved March 3, 2010, from http://www. denso-wave.com/qrcode/qrfeature-e.html

Edelson, D.C., Gordin, D.N., \& Pea, R.D. (1999). Addressing the challenges of inquiry-based learning through technology and curriculum design. Journal of the Learning Sciences, 8 (3/4), 391-450.

Doppen, F.H. (2004). Beginning social studies teachers' integration of technology in the history classroom. Theory and Research in Social Education, 32 (2), 248-279.

Forsyth, A. S., Jr. (1986). Applications of Microcomputer Search-Type Adventure Games in Research on Spatial Orientation, Place Location, and Memory for Places. Paper presented at the American Educational Research Association Meeting.

Ge, X., \& Land, S. (2003). Scaffolding students' problem-solving processes in an illstructured task using question prompts and peer interactions. Educational Technology Research and Development, 51(1), 21-38.

Ge, X., \& Land, S. M. (2004). A conceptual framework for scaffolding ill-structured problem-solving processes using question prompts and peer interactions. Educational Technology Research and Development, 52(2), 5-22.

Gokhale, A. (1995). Collaborative learning enhances critical thinking. Journal of Technology Education, 7, 22-30.

Hwang, G.-J., Tsai, C.-C., \& Yang, S. J. H. (2008). Criteria, strategies and research issues of context-aware ubiquitous learning. Educational Technology \& Society, 11 (2), 81-91.

Hwang, G.-J., Yang, T.-C., Tsai, C.-C., \& Yang, S. J. H. (2009). A context-aware ubiquitous learning environment for conducting complex science experiments. Computers \& Education, 53(2), 402-413.

Lapsansky-Werner, E., Levy, P., Roberts, R., \& Taylor, A. (2007). United States History. Boston: Pearson Prentice Hall.

LearnNC, (2008). Phone Category, Blog, Instructify. Retrieved March 4, 2010, from http://blogs.learnnc.org/instructify/ category/phone/

Li, D.D., \& Lim, C.P. (2008). Scaffolding online historical inquiry tasks: A case 
study of two secondary school classrooms. Computers \& Education, 50,1394-1410.

Light, G., Calkins, S., \& Cox, R. (2009). Learning and teaching in higher education: The reflective professional. New York: Sage.

Lim, B.R. (2004). Challenges and issues in designing inquiry on the Web. British Journal of Educational Technology, 35(5), 627-643.

Matei, S. A. (in press). Visible Past: A location and attention aware learning and discovery environment for digital humanities. International Journal of Humanities and Arts Computing.

Matei, S., (2009). What's new in the world of citation management? I Think Blog. Retrieved August 30, 2009, from http:// matei.org/ithink/2009/05/15/whats-newin-the-world-of-citation-management/

Matei, S., Miller, C., Arns, L., Rauh, N., Hartman, C., \& Bruno, R. (2007). Visible Past: Learning and discovering in real and virtual space and time. First Monday, 12(5).

Matei, S., Wernert, E., \& Faas, T. (2009). Where Information Searches for You: The Visible Past Ubiquitous Knowledge Environment for Digital Humanities. Paper presented at the Social Mobile Web.

Mayer, R. (2005). Cambridge Handbook of Multimedia Learning. Cambridge: Cambridge University Press.

Merrill,M.(2002). First principlesofinstruction. Educational Technology Research and Development, 50(3), 43-59.

Michie, M. (1998). Factors influencing secondary science teachers to organise and conduct field trips. Australian Science Teachers' Journal, 44(4), 43-50.

Molebash, P. (2004). Web historical inquiry projects. Social Education, 68 (3), 226-234.

National Council for the Social Studies. (1994). Expectations of excellence: Curriculum standards for social studies. Washington,
DC: National Council for the Social Studies.

O'Neill, D.K., \& Sohbat, E. (2004). How high schoolers account for different accounts: Developing a practical classroom measure of thinking about historical evidence and methodology. Paper presented at the annual meeting of the American Educational Research Association, San Diego, CA.

O'Reilly, T. (2005). What Is Web 2.0, Publication, Retrieved March 4, 2010, from http://www.oreilly.com/pub/a/oreilly/tim/ news/2005/09/30/what-is-web-20.html

Patten, B., Sanchez, I. A., \& Tangney, B. (2006). Designing collaborative, constructionist and contextual applications for handheld devices. Computers and Education, 46(3), 294-308.

Pulsinelli, A., \& Roubie, C. (2001). Using Diversity Modeling for Instructional Design. Performance Improvement, 40(7), 18-25.

Rogers, D., \& Swan, K. (2004). Self-regulated learning and internet searching. Teachers College Record, 106(9), 1804-1824.

Saye, J., \& Brush, T. (2002). Scaffolding critical reasoning about history and social issues in multimedia-supported learning environments. Educational Technology Research and Development, 50(3), 77-96.

Smith, D.H. (1996). Developing a more interactive classroom: A continuing odyssey. Teaching Sociology, 24(1), 64-75.

Smith, P. \& Ragan, T. (2004). Instructional design ( $3 r d$ ed.). New York: John Wiley \& Sons, Inc.

Sokoloff, D. R. \& Thornton, R. K. (1997). Using interactive lecture demonstrations to create an active learning environment. Physics Teacher, 35, 340-347.

Sopehr, K.T., \& Sopehr, L.W. (1994). Learning to think historically. Educational Psychologist, 29(2), 71-77.

Sunal, C. \& Sunal, D. (2003). Teacher candidates' conceptualization of guided 
inquiry and lesson planning following webassisted instruction. Theory and Research in Social Education, 31(2), 243-264.

Virtual Omaha Beach Showcase. (2010). Retrieved March 3, 2010, from http:// visiblepast.net/gwiki2/index.php?title =Category:Omaha/WN

W3schools. (2010). Browser Statistic. Retrieved April 17, 2010, from http://www.w3schools. com/browsers/browsers_stats.asp

Wallace, R., J. Kupperman, J., J. Krajcik, J., \& E. Soloway, E. (2000). Science on the Web: students online in a sixth-grade classroom. Journal of the Learning Sciences, 9 (1), 75-104.

Wang, F., \& Hannafin, M. (2005). Design-based research and technology-enhanced learning environments. Educational Technology Research and Development, 53(4), 5-23.

Wegner, S.B., Holloway, K.C., \& Garton, E.M. (1999). The effects of Internet-based instruction on student learning. Journal of Asynchronous Learning Networks, 3(2), 98-106.

Wiley, J., \& Ash, I. K. (2005). Multimedia learning of history. In R.E.Mayer (Ed.), The Cambridge Handbook of Multimedia Learning. New York: Cambridge University Press.

Zaloga, S. (2005). D-Day Fortifications in Normandy. Osprey Publishing.

\section{Acknowledgement Note}

The authors express their sincere gratitude to Dr. Sorin A. Matei for his guidance in designing the course module and his provision of platform content.

\section{Contact the Authors}

\section{Xiaojun Chen}

Purdue University, USA

E-mail:xjchen@purdue.edu

\section{Jea H. Choi}

Purdue University, USA

E-mail: choi65@purdue.edu 


\section{Appendix 1 Lesson Plan for Omaha Beach}

\begin{tabular}{|c|c|}
\hline Title and Grade & D Day Omaha Beach in World War II / High School Grade 10 \\
\hline Overview & $\begin{array}{l}\text { Students will practice historical inquiry skills to obtain historical content knowledge by engaging } \\
\text { in an interactive learning environment. Students will learn about World War II. Students will } \\
\text { discover the events in Omaha Beach. }\end{array}$ \\
\hline & 1. Students will be able to identify key events and key person in Omaha Beach battle. \\
\hline Objective & $\begin{array}{l}\text { 2. Students will be able to analyze historical influence of United States in World War II. } \\
\text { 3. Students will be able to utilize interactive website to engage in inquiry-based learning } \\
\text { environment. }\end{array}$ \\
\hline & Social Studies - World History and Civilization \\
\hline & $\begin{array}{l}\text { An Era of Global Conflicts, Challenges, Controversies, and Changes: } 1900 \text { to the Present } \\
\text { WH.8 Students will analyze and explain trends and events of global significance, such as world } \\
\text { wars and international controversies and challenges, and cross-cultural changes that have } \\
\text { connected once-separated regions into an incipient global community. } \\
\text { WH.8.4 Identify and analyze the causes, events, and consequences of World War II. }\end{array}$ \\
\hline Standards & Social studies - United States History \\
\hline & $\begin{array}{l}\text { The United States and World War II: } 1939 \text { to } 1945 \\
\text { USH. } 5 \text { Students will examine the causes and course of World War II, the effects of the war on } \\
\text { United States society and culture, and the consequences of the war on United States involvement } \\
\text { in world affairs. } \\
\text { USH.5.2 Identify and describe key events that resulted in the United States entry into World War II. } \\
\text { USH.5.3 Identify and describe key leaders and events during World War II. }\end{array}$ \\
\hline Materials & Website (ubimark code, Google map, text information, picture, short movie clips), Handouts \\
\hline & $\begin{array}{l}\text { Phase } 1 \\
\text { - Class will be divided to three teams. Each team will be assigned to certain area of Omaha } \\
\text { Beach with IPhone or Ipod provided to each team (or use the website for access). } \\
\text { - Students will research on the events that happen in their assigned area by using the Visible Past site. } \\
\text { - Handouts will be given with ubimark map code: As a team, students will have to fill out the } \\
\text { areas of the map, event, summary (time, location, countries included, US's role.) } \\
\text { - Each team will present their findings to the whole class. } \\
\text { - Students participate in online discussion in team area. }\end{array}$ \\
\hline Procedure & $\begin{array}{l}\text { Phase } 2 \\
\text { - All teams collaborate their events, and align them together according to the time line. } \\
\text { - Along with the time line, students will mark the events of D-day on the map and see how the } \\
\text { events flow with the time. }\end{array}$ \\
\hline & $\begin{array}{l}\text { Phase } 3 \\
\text {-Student participate in discussion board with reflection questions and discussion questions. } \\
\text {-Students need to find and share an interesting story in that event online. } \\
\text {-Students can add more information to the Visible Past page if they found more resources -- } \\
\text { write their names on the page as a contributor) }\end{array}$ \\
\hline & Handout \\
\hline Evaluation & $\begin{array}{l}\text { Reflection notes } \\
\text { Online participation }\end{array}$ \\
\hline
\end{tabular}

